\title{
PENGARUH PROFIT MARGIN DAN TURNOVER OF OPERATING ASSSETS TERHADAP RENTABILITAS EKONOMI PADA LEMBAGA PEKREDITAN DESA DI KECAMATAN SUSUT PERIODE 2014-2015
}

\author{
I Wayan Bayudinata ${ }^{1}$, Made Ary Meitriana ${ }^{2}$, I Nyoman Sujana ${ }^{3}$ \\ Jurusan Pendidikan Ekonomi \\ Universitas Pendidikan Ganesha \\ Singaraja, Indonesia
}

\begin{abstract}
e-mail: dinata bayu@yahoo.com ${ }^{1}$, ary.meitriana@yahoo.co.id ${ }^{2}$, sujanatbn@gmail.com ${ }^{3}$
\end{abstract}

\begin{abstract}
Abstrak
Penelitian ini bertujuan untuk mengetahui, pengaruh profit margin terhadap rentabilitas ekonomi, pengaruh turnover of operating assets terhadap rentabilitas ekonomi, pengaruh profit margin dan turnover of operating assets terhadap rentabilitas ekonomi pada LPD di Kecamatan Susut periode 2014-2015. Penelitian ini merupakan jenis penelitian kausal dengan pendekatan kuantitatif. Data dikumpulkan dengan menggunakan metode dokumentasi. Hasil penelitian ini menunjukkan bahwa, Profit margin berpengaruh terhadap rentabilitas ekonomi pada LPD di Kecamatan Susut periode tahun 2014-2015, Turnover of operating assets tidak berpengaruh terhadap rentabilitas ekonomi pada LPD di Kecamatan Susut periode tahun 2014-2015, Profit margin dan Turnover of operating assets berpengaruh terhadap rentabilitas ekonomi pada pada LPD di Kecamatan Susut periode tahun 2014-2015. Hal ini ditunjukan dengan nilai $\mathrm{F}_{\text {hitung }}=18,987>\mathrm{F}_{\text {tabel }}=3,12$ atau $\mathrm{p}$-value $=0,00<a=0,05$.
\end{abstract}

Kata kunci: Profit margin, Turnover of Operating Assets dan Rentabilitas Ekonomi

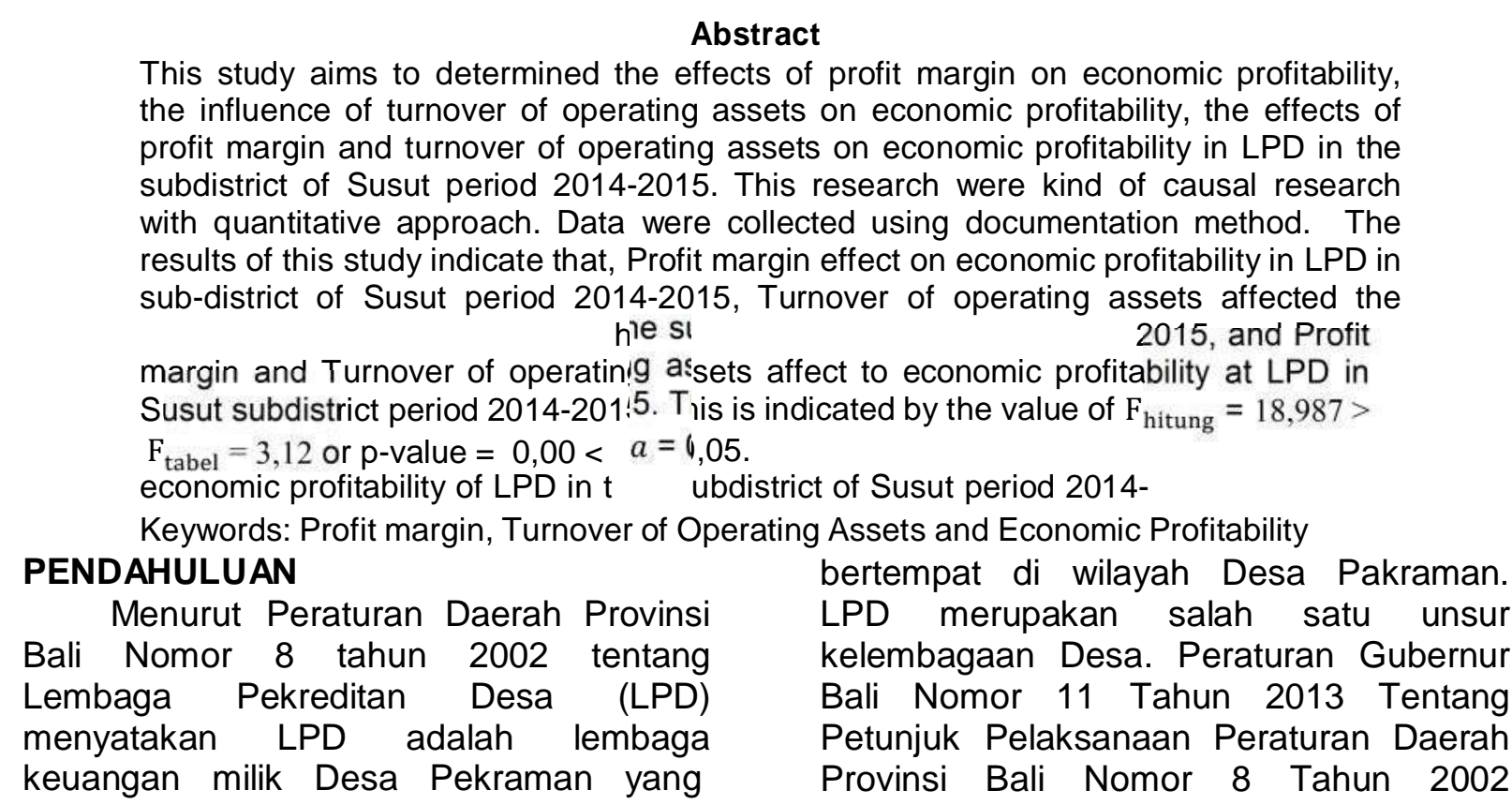


Tentang Lembaga Pekreditan Desa Sebagaimana Telah Diubah Beberapa Kali Terakhir Dengan Peraturan Daerah Provinsi Bali Nomor 4 Tahun 2012 Tentang Perubahan Kedua Atas Peraturan Daerah Prvinsi Bali Nomor 8 Tahun 2002 Tentang Lembaga Pekreditan Desa menyebutkan earning atau rentabilitas adalah salah satu dari lima faktor yang berpengaruh terhadap kondisi dan perkembangan LPD sebagai lembaga keuangan, rentabilitas memiliki beberapa komponen yang diberikan bobot sebagai penentu kesehatan LPD. Menurut Riyanto (2001:35) Rentabilitas adalah kemampuan suatu perusahaan untuk menghasilkan laba selama periode tertentu, dan umumnya dirumuskan sebagai jumlah laba yang diperoleh selama periode tertentu dibagi modal atau aktiva yang digunakan untuk menghasilkan laba tersebut. Menurut Riyanto (2001) Cara untuk menilai rentabilitas suatu perusahaan adalah bermacam-macam dan tergantung pada laba dan aktiva atau modal mana yang akan diperbandingkan satu dengan yang lainnya. Dalam penelitian ini cara yang digunakan untuk menilai rentabilitas adalah rentabilitas ekonomi. Menurut Riyanto (2001) Rentabilitas ekonomi ialah perbandingan laba usaha dengan modal asing dan modal sendiri yang dipergunakan untuk menghasilkan laba tersebut dan dinyatakan dalam presentase. Oleh karena pengertian rentabilitas sering dipergunakan untuk mengukur efisiensi penggunaan modal di dalam suatu perusahaan, maka rentabilitas ekonomi sering pula dimaksudkan sebagai kemampuan suatu perusahaan dengan seluruh modal yang bekerja di dalamnya untuk menghasilkan laba. Modal yang diperhitungkan untuk menghitung rentabilitas ekonomi hanyalah modal yang bekerja di dalam perusahaan (operating capital/assets). Dengan demikian maka modal yang ditanamkan dalam perusahaan lain atau modal yang ditanamkan dalam efek (kecuali perusahaan-perusahaan kredit) tidak diperhitungkan dalam menghitung rentabilitas ekonomi. Demikian pula laba yang diperhitungkan untuk menghitung rentabilitas ekonomi hanyalah laba yang berasal dari operasi perusahaan, yaitu yang disebut laba usaha (net operating income). Dengan demikian maka yang diperoleh dari usaha-usaha di luar perusahaan atau dari efek (misalnya deviden, coupon dan lain-lain) tidak diperhitungkan dalam menghitung rentabilitas ekonomi. Untuk mengetahui apa saja yang dapat mempengaruhi rentabilitas maka harus diketahui faktorfaktor yang mempengaruhi rentabilitas ekonomi atau earning power. Menurut Riyanto (2001:37) faktor-faktor yang menentukan tinggi rendahnya rentabilitas ekonomi atau earning power ditentukan oleh 2 faktor yaitu Profit Margin dan Turnover of Operating Assets. Profit Margin yaitu perbandingan antara net operating income dengan net sales, perbandingan mana dinyatakan dalam presentase Net Operating Income dibagi Net Sales. Turnover of operating assets (tingkat perputaran aktiva usaha), yaitu kecepatan berputarnya operating assets dalam suatu periode tertentu. Turnover tersebut dapat ditentukan dengan membagi net sales dengan operating assets. Dalam hal ini profit margin dimaksudkan untuk mengetahui efisiensi perusahaan dengan melihat besar kecilnya laba usaha dalam hubungannya dengan sales, sedangkan operating assets turnover dimaksudkan untuk mengetahui efisiensi perusahaan dengan melihat kecepatan perputaran operating assets dalam suatu periode tertentu. Hasil akhir dari percampuran kedua efisiensi profit margin dan operating assets turnover menentukan tinggi rendahnya rentabilitas. Oleh karena itu makin tingginya tingkat profit margin atau operating assets turnover masing-masing atau kedua-duanya akan mengakibatkan naiknya rentabilitas.

Menurut Kasmir (2008:297) "rasio rentabilitas sering disebut profitabilitas usaha. Rasio ini digunakan untuk mengukur tingkat efisiensi usaha dan profitabilitas yang dicapai oleh bank yang bersangkutan. Laba yang diraih dari kegiatan yang dilakukan merupakan cerminan kinerja sebuah perusahaan dalam menjalankan usahanya". Lebih 
lanjut Menurut Sartono (2010: 122) "rentabilitas adalah suatu kemampuan perusahaan untuk memperoleh laba atau keuntungan dalam hubungannya dengan penjualan, total aktiva maupun modal sendiri". Hampton (1980: 110) (dalam Jumingan 2008: 122) menyatakan, "rasio profitabilitas, bertujuan mengukur efisiensi aktivitas perusahaan dan kemampuan perusahaan untuk memperoleh keuntungan. Misalnya margin keuntungan (profit margin), margin laba bruto (gross profit margin), perputaran aktiva (operating assets turnover), rentabilitas modal sendiri (return on equity) dan sebagainya".

Adapun Weston \& Brigham (dalam Jumingan 2008: 122) menyatakan "rasio profitabilitas, bertujuan mengukur efektifitas manajemen yang tercermin pada imbalan hasil dari investasi melalui kegiatan penjualan. Misalnya profit margin on sales, return on total asset, return on net worth, dan sebagainya". Muslich (2007) menyatakan pengukuran tingkat profitabilitas dapat dilakukan dengan membandingkan tingkat Return on Investment (ROI) yang diharapkan dengan tingkat return yang diminta oleh investor dalam pasar modal. Jika hasil yang diharapkan lebih besar daripada hasil yang diminta, maka investasi tersebut dikatakan sebagai menguntungkan. Rasio profitabilitas tergantung dari informasi yang diambil dari laporan keuangan. Karenanya profitabilitas dalam konteks analisis rasio, mengukur pendapatan menurut laporan Rugi Laba dengan nilai buku investasi. Rasio profitabilitas ini, kemudian, dapat dibandingkan rasio yang sama perusahaan pada tahun lalu atau rasio rata-rata industri.

Munawir (dalam Suyadi:2003) Penggunaan rentabilitas sebagai kriteria penilaian hasil operasi perusahaan mempunyai tujuan pokok yang dapat dibagi sebagai berikut Pertama sebagai suatu indikator tentang efektifitas dan efisiensi manajemen. Rentabilitas merupakan salah satu faktor yang menarik perhatian bagi analis, karena mampu menggambarkan kriteria yang sangat diperlukan untuk menilai kesuksesan perusahaan sebagai manifestasi dari efektifitas dan efisiensi, serta kwalitas manajemen.

Kedua sebagai alat untuk membuat proyeksi laba perusahaan. Rentabilitas menggunakan korelasi antara laba dan jumlah modal yang ditanamkan, maka sangat membantu para analisis untuk membuat proyeksi laba pada berbagai tingkat perubahan jumlah modal yang ditanamkan pada jenis usaha yang bersangkutan.

Ketiga sebagai alat pengendali bagi manajemen. Bagi pihak intern manajemen khususnya dan rentabilitas digunakan sebagai alat untuk menyusun rencana (target) budget, koordinasi, evaluasi hasil pelaksanaan operasi perusahaan, kriteria penilaian alternatif dan dasar keputusan penanaman modal. Sedangkan bagi pihak luar yaitu kreditur, pemerintah dan lain-lain mempunyai tujuan. khususnya seperti pajak yang akan dibayar, kemampuan perusahaan mendapatkan laba sehingga dapat melunasi semua hutang-hutangnya dan kemampuan keuangan lainnya. Walaupun rentabilitas ekonomis secara individual tidak mampu menggambarkan hasil operasi secara keseluruhan akan tetapi merupakan kriteria penilaian paling valid.

Dari beberapa pendapat ahli diatas dapat disimpulkan bahwa rentabilitas adalah rasio yang dapat menunjukan kemampuan suatu perusahaan untuk menghasilkan laba selama periode tertentu. Semakin tinggi nilai rentabilitas maka kemampuan perusahaan dalam menghasilkan laba semakin baik. Hal ini dapat dipahami karena dalam menghitung nilai rentabilitas laba bandingkan dengan modal, jadi jika modal tetap dan laba semakin tinggi maka nilai rentabilitasnya akan semakin tinggi. Melalui rasio ini dapat dilihat efisiensi usaha yang dicapai perusahaan dalam menggunakan modal untuk memperoleh laba. Rentabilitas dapat dicari dengan membandingkan laba dengan aktiva atau modal yang menghasilkan laba tersebut dikali 100 persen.

Adapun faktor-faktor yang mempengaruhi rentabilitas ekonomi menurut beberapa ahli sebagai berikut. Menurut Hanafi \& Halim (dalam Elvandari 
2007:77-81) faktor-faktor yang mempengaruhi rentabilitas yang pertama adalah likuiditas, rasio lancar yang rendah yang dapat dikatakan bahwa perusahaan dalam keadaan yang illikuid, menunjukkan risiko likuiditas yang tinggi (perusahaan tidak dapat membayar hutang lancarnya), sehingga perusahaan tidak dapat menghasilkan laba dan berakibat pada tingkat rentabilitas ekonomi yang tidak rendabel.

Kedua solvabilitas merupakan kemampuan perusahaan untuk memenuhi semua hutang baik jangka pendek maupun jangka panjang. Jika perusahaan tidak dapat membayar semua hutanghutangnya maka akan menimbulkan beban tetap bagi perusahaan sehingga menyebabkan tingkat rentabilitas ekonomi yang tidak rendabel.

Menurut Wasis (dalam Elvandari 2010) faktor-faktor yang mempengaruhi rate of return (rentabilitas ekonomi) adalah Pertama volume penjualan, salah satu indikator untuk mengetahui kemajuan suatu perusahaan adalah penjualan. Dengan semakin bertambahnya penjualan maka akan menaikan volume pendapatan yang diperoleh perusahaan sehingga biaya-biaya akan tertutup juga. Hal ini mendorong perusahaan untuk mengefektifkan modal untuk mengembangkan usahanya.

Kedua efisiensi penggunaan biaya, modal yang diperoleh perusahaan untuk mengembangkan usahanya harus dipelihara dan dipertanggungjawabkan secara terbuka. Dengan kata lain penggunaan modal harus digunakan untuk usaha yang tepat dengan pengeluaran yang hemat sehingga keberhasilan usaha akan tercapai, secara tidak langsung pula akan mempengaruhi tingkat rentabilitas.

Ketiga profit margin, profit margin adalah laba yang diperbandingkan dengan penjualan. Profit margin digunakan untuk mengukur tingkat keuntungan yang dapat dicapai oleh perusahaan berkaitan dengan penjualan perusahaan.

Keempat struktur modal perusahaan, struktur modal adalah pembiayaan pembelanjaan permanen perusahaan yang terutama pada hutang jangka panjang, saham preferen atau prioritas dan modal saham biasa, tetapi tidak termasuk hutang jangka pendek.

Dari beberapa pendapat ahli diatas dapat disimpulkan bahwa faktor-faktor yang mempengaruhi rentabilitas ekonomi adalah profit margin, turnover of operating assets, volume penjualan, efisiensi penggunaan biaya, dan struktur modal perusahaan.

Variabel bebas yang pertama dalam penelitian ini adalah profit margin, berikut ini adalah beberapa pengertian tentang profit margin menurut para ahli. Menurut Weston \& Copeland (dalam Nurmalasari 2009) menyatakan Net Profit Margin merupakan perbandingan antara laba bersih dengan penjualan. Rasio ini sangat penting bagi manajer operasi karena mencerminkan strategi penetapan harga penjualan yang diterapkan perusahaan dan kemampuannya untuk mengendalikan beban usaha. Semakin besar Net Profit Margin berarti semakin efisien perusahaan tersebut dalam mengeluarkan biayabiaya sehubungan dengan kegiatan operasinya.. Husnan (2012), menyatakan bahwa rasio profit margin mengukur seberapa banyak keuntungan operasional bisa diperoleh dari setiap rupiah penjualan. Karena itu rasionya dinyatakan sebagai, Profit margin sama dengan laba operasi dibagi penjualan dikali seratus persen".

Lebih lanjut Kasmir (2010:115), menyatakan "Profit Margin on sales atau rasio profit margin atau margin laba atas penjualan merupakan salah satu rasio yang digunakan untuk mengukur margin laba atas penjualan. Untuk mengukur rasio ini adalah dengan cara membandingkan antara laba bersih setelah pajak dengan penjualan.

Dari beberapa pendapat ahli diatas maka dapat disimpulkan bahwa profit margin adalah perbandingan antara net operating income atau laba usaha dengan net sales atau penjualan bersih. Penggunaan rasio ini adalah untuk mengetahui efisiensi perusahaan melalui besar kecilnya laba dalam hubungannya dengan penjualan. Rasio profit margin mempengaruhi tinggi rendahnya rentabilitas ekonomi, hal ini karena rasio profit margin melihat efisiensi perusahaan melalui penjualan, hal ini dapat dimengerti 
karena dengan bertambah atau berkurangnya penjualan maka akan menaikan atau menurunkan volume pendapatan yang diperoleh perusahaan. Jika volume pendapatan yang didapatkan perusahaan meningkat maka hal ini akan menutupi biaya-biaya yang ada, semakin baik pendapatan bisa menutupi biayabiaya maka akan meningkatkan laba. Dengan keadaan yang demikian maka dapat dikatakan bahwa modal yang digunakan perusahaan efisien.

Variabel yang bebas yang kedua adalah turnover of operating assets, Kasmir (2010:114), menyatakan "Perputaran Aktiva (Assets Turnover), Merupakan rasio yang digunakan untuk mengukur perputaran semua aktiva yang dimiliki perusahaan. Kemudian juga mengukur berapa jumlah penjualan yang diperoleh dari tiap rupiah aktiva". Sedangkan Husnan (2012) menyatakan rasio perputaran aktiva mengukur seberapa banyak penjualan bisa diciptakan dari setiap rupiah yang dimiliki. Karena itu rasionya adalah, Perputaran aktiva sama dengan penjualan dibagi ratarata aktiva. Lebih lanjut Sartono (2001) membagi dua pengertian mengenai perputaran aktiva yaitu perputaran aktiva tetap dan perputaran total aktiva. Perputaran aktiva tetap adalah rasio antara penjualan dengan aktiva tetap neto. Rasio ini menunjukan bagaimana perusahaan menggunakan aktiva tetapnya seperti gedung, kendaraan, mesin-mesin, perlengkapan kantor. Sedangkan perputaran total aktiva menunjukan bagaimana efektifitas perusahaan menggunakan keseluruhan aktiva untuk menciptakan penjualan dan mendapatkan laba.

Dengan demikian dari beberapa pendapat ahli tersebut dapat disimpulkan bahwa turnover of operating assets adalah perputaran aktiva usaha dalam suatu periode tertentu. Melalui turnover of operating assets atau tingkat perputaran aktiva usaha dapat dilihat efisiensi dari modal usaha yang digunakan perusahaan. Dalam hal ini akan dapat dilihat berapa kali modal usaha berputar dalam suatu periode untuk menghasilkan penjualan atau sales. Semakin besar rasio ini akan menunjukan semakin baik perusahaan dalam menggunakan modal usaha terutama untuk menghasilkan penjualan.

Berdasarkan data yang ditemukan dilapangan yaitu pada pengamatan awal ada 4 LPD dari 38 LPD yang akan diteliti antara lain adalah LPD Desa Tiga, Desa Abuan, Desa Manuk, dan Desa Kikian yang mengalami tingkat penurunan rentabilitas ekonomi dari periode tahun 2014 sampai periode tahun 2015. Pada LPD Desa Tiga tahun 2014 rentabilitasnya adalah 2.85 persen, pada tahun 2015 rentabilitasnya adalah 2.76 persen. Pada LPD Desa Abuan tahun 2014 rentabilitasnya adalah 4.96 persen, tahun 2015 rentabilitasnya adalah 4.35 persen, Pada LPD Desa Manuk tahun 2014 rentabilitasnya adalah 5.17 persen, pada tahun 2015 rentabilitasnya adalah 5.11 persen. Pada LPD Desa Kikian tahun 2014 rentabilitasnya adalah 5.23 persen, pada tahun 2015 rentabilitasnya adalah 5.00 persen. Dilihat dari keempat LPD tersebut, semua LPD mengalami penurunan tingkat rentabilitas ekonomi dari tahun ke tahun yang mungkin dipengaruhi oleh profit margin dan turnover of operating assets

\section{METODE}

Rancangan penelitian dalam penelitian ini merupakan penelitian kausal. Menurut Sugiyono (2010:56) desain penelitian kausal adalah "hubungan yang bersifat sebab akibat" ", variabel bebas dalam penelitian ini adalah profit margin dan turnover of operating assets merupakan variabel yang mempengaruhi dan variabel terikat dalam penelitian ini adalah rentabilitas ekonomi.

Pengumpulan data dilakukan dengan menggunakan Metode dokumentasi. Metode dokumentasi merupakan cara pengumpulan data penelitian dengan mengkaji dokumen-dokumen yang diperlukan untuk menyimpulkan data penelitian. Dokumen-dokumen yang dipergunakan dalam penelitian ini adalah laporan keuangan LPD.

Populasi dalam penelitian ini adalah seluruh LPD yang ada di Kecamatan Susut tahun 2014-2015 yang berjumlah 38 LPD. Sampel merupakan bagian dari 
populasi yang dapat mewakili dalam sebuah penelitian. Sampel dalam penelitian ini yakni seluruh populasi yang terdiri dari 38 LPD yang ada di Kecamatan tahun 2014-2015.

Uji asumsi klasik merupakan dasar dari teknik sanalisis regresi. Uji asumsi klasik diperlukan untuk mengetahui apakah data sudah layak untuk analisis lebih lanjut. Dalam penggunaan regresi linear rentan dengan beberapa permasalahan yang sering timbul, sehingga akan menyebabkan hasil dari penelitian yang telah dilakukan menjadi kurang akurat. Oleh karena itu dilakukan uji asumsi klasik sebagai berikut:

Uji Normalitas dilakukan untuk melihat apakah variabel bebas dan variabel terikat mempunyai distribusi normal. Tujuan dari pengujian ini adalah untuk mengetahui apakah dalam sebuah model regresi, error yang dihasilkan mempunyai distribusi normal atau tidak.Uji normalitas dapat dilihat melalui normal probability plot. Data yang berdistribusi normal adalah data yang mengikuti arah garis diagonal dan menyebar disekitar garis diagonal. Dasar pengambilan keputusan dalam uji normalitas adalah jika data menyebar disekitar garis diagonal dan mengikuti arah garis diagonal, maka model memenuhi asumsi normalitas. Jika data menyebar dari garis diagonal dan atau tidak mengikuti arah garis diagonal, maka model tidak memenuhi asumsi normalitas.

Uji Multikoleniaritas yaitu munculnya peluang diantara beberapa variabel bebas untuk saling berkorelasi, pada praktiknya multikolinieritas tidak dapat dihindari. Tujuan uji multikolinieritas adalah menguji apakah pada sebuah model regresi ditemukan adanya korelasi antar Independent Variabel. Jika terjadi korelasi, maka dinamakan terdapat problem Multikolinearitas (Multiko). Mengukur multikolinieritas dapat dilihat dari nilai TOL (Tolerance) dan VIF (Varian Inflation Faktor). Nilai cutoff yang umum dipakai untuk menunjukkan adanya multikolonieritas adalah nilai apabila VIF> 10 terdapat multikolinieritas, jikaVIF $<10$ tidak terdapat multikolinieritas.

Uji heteroskedastisitas bertujuan untuk menguji apakah dalam model regresi terjadi ketidak samaan varian dari residual satu pengamatan kepengamatan yang lain. Model regresi yang baik adalah tidak heteroskedastisitas. Uji ini dapat dilakukan dengan melihat gambar scattrplot antara nilai prediksi variabel bebas ZPRED (nilai prediksi sumbu $X$ ) dengan residualnya SRESID (nilai residualnya, sumbu Y). Apabila pada grafik tersebut tidak terdapat pola tertentu yang teratur, secara acak di atas dan di bawah angka 0 pada sumbu $\mathrm{Y}$, maka diidentifikasi tidak terdapat heteros kedastisitas.

Uji Autokorelasi bertujuan menguji apakah dalam model regresi linier ada korelasi antara kesalahan pengganggu pada periode $t$ dengan kesalahan pengganggu pada periode $t-1$ sebelumnya. Salah satu uji formal yang paling populer untuk mendeteksi autukrelasi adalah uji Durbin-Watson, dasar engambilan keputusan ada tidaknya gejala autokorelasi (Ghozali, 2011:111). Syarat jika tidak terjadi autokorelasi adalah membandingkan t-(hitung) Durbin Watson dengan t-tabel durbin Watson $(\mathrm{DU}<\mathrm{DW}<4-\mathrm{DU})$

\section{HASIL DAN PEMBAHASAN HASIL}

Pengaruh profit margin dan turnover of operating assets secara parsial terhadap rentabilitas ekonomi pada LPD di Kecamatan Susut periode 2014-2015 dengan uji statistik t-tes.

Pengaruh profit margin dan turnover of operating assets terhadap rentabilitas ekonomi pada LPD di Kecamatan Susut periode 2014-2015 dengan uji statistik ttes dianalisis dengan program software SPSS 16.0 Windows. Hasil analisis tersebut dapat dilihat pada tabel 1 dan 2 . 
Tabel 1. Hasil Uji t Pengaruh Profit Margin Terhadap Rentabilitas Ekonomi

Coefficients $^{a}$

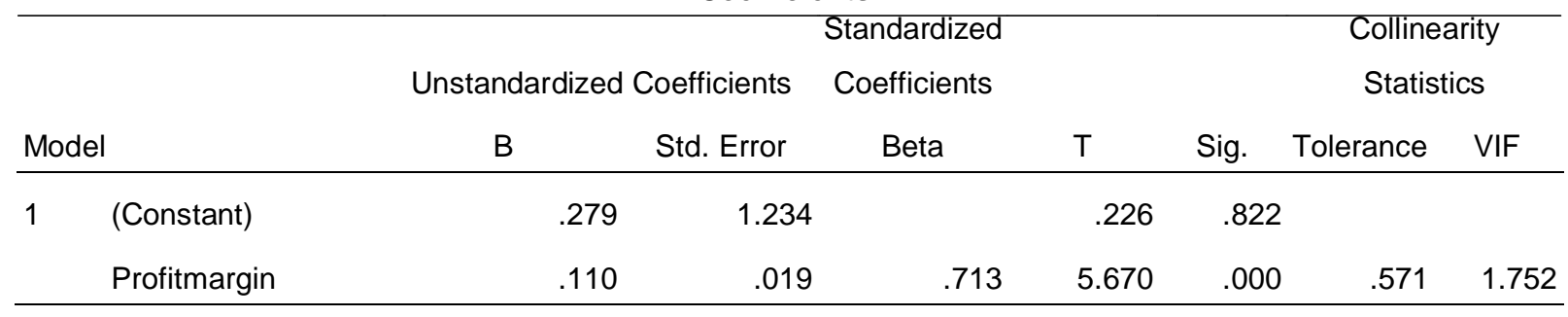

a. Dependent Variable: rentabilitasEkonomi

Dari tabel 1 diketahui bahwa variabel profit margin berpengaruh signifikan terhadap variabel rentabilitas ekonomi karena, nilai t-hitung $=5.670>\mathrm{t}$-tabel $=$ 1,66571 atau $p$-value $=0,00<a=0,05$ maka Ha1 diterima. Kesimpulannya

adalah variabel profit margin secara parsial berpengaruh terhadap rentabilitas ekonomi pada Lembaga Pekreditan Desa (LPD) di Kecamatan Susut periode tahun 2014-2015.

Tabel 2. Hasil Uji t Pengaruh Turnover of Operating Assets Terhadap Rentabilitas Ekonomi

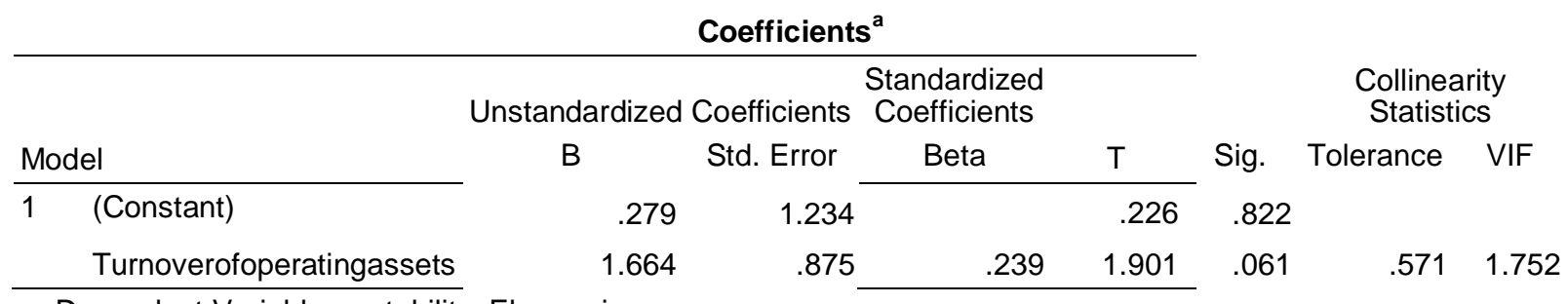

a. Dependent Variable: rentabilitasEkonomi

Dari tabel 2 dapat diketahui, turnover of operating assets tidak berpengaruh terhadap variabel rentabilitas ekonomi. Hal ini ditunjukkan dengan nilai t-hitung = $1.901>t$-tabel $=1,66571$ tetapi nilai $p$-value $=0,061>a=0,05$ maka $\mathrm{H} 2$ ditolak. Kesimpulannya adalah variabel turnover of operating assets tidak berpengaruh terhadap rentabilitas ekonomi pada perusahaan pada Lembaga Pekreditan Desa (LPD) di Kecamatan Susut periode tahun 2014-2015. Hal ini karena dari analisis data rata-rata turnover of operating assets pada Lembaga Pekreditan Desa di Kecamatan Susut periode 2014 adalah sebesar 0.56 kali perputarannya dan rata-rata turnover of operating assets pada Lembaga Pekreditan Desa di Kecamatan Susut periode 2015 adalah 0,59 kali.

Dari rata-rata turnover of operating assets yang kecil menunjukan bahwa secara rata-rata modal usaha pada
Lembaga Pekreditan Desa di Kecamatan Susut periode 2014-2015 tidak banyak berputar dalam menghasilkan penjualan. Penjualan yang rendah secara langsung akan mengurangi nilai laba usaha, karena laba usaha didapat dari penjualan dukurangi biaya-biaya.

Pengaruh profit margin dan turnover of operating assets secara simultan terhadap rentabilitas ekonomi pada Lembaga Pekreditan Desa di Kecamatan Susut periode 2014-2015 dengan uji statistik F-tes.

Untuk mengetahui pengaruh secara simultan variabel profit margin dan turnover of operating assets terhadap rentabilitas ekonomi pada Lembaga Pekreditan Desa di Kecamatan Susut periode 2014-2015 dengan uji statistik Ftes dengan program software SPSS 16.0 Windows. Hasil analisis tersebut dapat dilihat pada tabel 3 . 
Tabel 3. Hasil Perhitungan Uji F Pengaruh Profit Margin dan Turnover of Operating Assets Terhadap Rentabilitas Ekonomi

\begin{tabular}{|c|c|c|c|c|c|c|c|}
\hline \multirow{2}{*}{\multicolumn{2}{|c|}{ Model }} & \multirow[b]{2}{*}{ Sum of Squares } & \multicolumn{3}{|c|}{ ANOVA $^{b}$} & \multirow{3}{*}{$\begin{array}{l}F \\
18.957\end{array}$} & \multirow{3}{*}{$\begin{array}{l}\text { Sig. } \\
.000^{\circ}\end{array}$} \\
\hline & & & Df & & Mean Square & & \\
\hline \multirow[t]{3}{*}{1} & Regression & 168.710 & & 2 & 84.355 & & \\
\hline & Residual & 324.831 & & 73 & 4.450 & & \\
\hline & Total & 493.542 & & 75 & & & \\
\hline
\end{tabular}

a. Predictors: (Constant), Turnoverofoperatingassets, Profitmargin

b. Dependent Variable: rentabilitasEkonomi

Berdasarkan hasil analisis pada tabel 3 menunjukkan bahwa nilai F-hitung $=18.957>\mathrm{F}$-tabel $=3,12$ atau $\mathrm{p}$-value $=$ $0,00<a=0,05$ maka $\mathrm{H} 3$ diterima. Kesimpulannya adalah variabel profit margin dan turnover of operating assets memiliki pengaruh yang signifikan secara simultan terhadap rentabilitas ekonomi.
Untuk mengetahui besarnya pengaruh profit margin dan turnover of operating assets terhadap rentabilitas ekonomi, dapat digunakan analisis koefisien determinasi (Adjusted $\mathrm{R}$ Square). Besarnya koefisien determinasi (Adjusted R Square) dapat dilihat pada tabel

Tabel 4. Hasil perhitungan Koefisisen Determinasi (Adjusted R Square)

\begin{tabular}{|c|c|c|c|c|}
\hline \multirow[b]{3}{*}{ Model } & \multirow[b]{3}{*}{$\mathrm{R}$} & \multirow[b]{3}{*}{ R Square } & \multicolumn{2}{|c|}{ Model Summary } \\
\hline & & & Adjusted R & Std. Error of the \\
\hline & & & Square & Estimate \\
\hline 1 & $.585^{\mathrm{a}}$ & .342 & .324 & 2.10944 \\
\hline
\end{tabular}

\begin{tabular}{c}
\hline Durbin-Watson \\
\hline 2.328 \\
\hline
\end{tabular}

a. Predictors: (Constant), Turnoverofoperatingassets, Profitmargin

b. Dependent Variable: rentabilitasEkonomi

Berdasarkan hasil analisis pada tabel 4. dengan menggunakan program software SPSS 16.0 Windows menunjukan bahwa besar pengaruh antara variabel profit margin dan turnover of operating assets terhadap rentabilitas ekonomi adalah sebesar 0,324 artinya sebesar $32,4 \%$ variabel profit margin (X1), dan turnover of operating assets (X2), secara simultan berpengaruh terhadap Rentabilitas Ekonomi.

Data dalam penelitian ini sebelum diregresikan dan diperoleh persamaan regresi, telah dilakukan pengujian asumsi klasik agar diketahui apakah data layak untuk dianalisis lebih lanjut. Uji asumsi klasik meliputi uji normalitas dengan normal probability plot, menunjukkan data menyebar disekitar garis diagonal dan mengikuti arah garis diagonal maka dapat dikatakan model memenuhi asumsi normalitas. Uji Multikolinieritas dengan melihat nilai inflation faktor (VIF) menunjukkan nilai VIF seluruh variabel bebas baik profit margin dan turnover of operating assets < 10 maka dapat diketahui dalam model ini tidak terdapat masalah Multikolinieritas. Uji Heteroskedastisitas dengan melihat gambar scattrplot menunjukkan pada grafik tersebut tidak terdapat pola tertentu yang teratur, data menyebar secara acak di atas dan di bawah angka 0 pada sumbu $\mathrm{Y}$, maka diidentifikasi tidak terdapat heteroskedastisitas. Uji Autokorelasi dengan Durbin-Watson menunjukkan bahwa nilai Durbin-Watson (DW) yaitu 2,328 sedangkan (DU) pada taraf $k=2$ dan $\mathrm{n}=76$ yaitu 1,65413 . Syarat jika tidak terjadi autokorelasi adalah 
membandingkan thitung Durbin Watson dengan ttabel Durbin Watson (DU $<$ DW < 4 - DU). $(1,65413<2,328<2,34578)$ dari hasil ini dapat diketahui bahwa tidak terjadi masalah autokorelasi positif maupun negatif pada model. Hasil output uji asumsi klasik agar lebih jelas dapat dilihat pada lampiran, karena data seluruhnya telah melewati uji asumsi klasik dan dinyatakan layak maka dapat dibuat persamaan regresi.

Persamaan regresi yang dapat dibuat untuk menggambarkan pengaruh profit margin, dan turnover of operating assets terhadap rentabilitas ekonomi adalah $\hat{Y}=0.279+0.110 \times 1+1.664 \times 2+\mu$. Konstanta sebesar 0.279 menyatakan bahwa jika variabel bebas dianggap konstan atau bernilai 0 , maka rentabilitas ekonomi adalah sebesar 0.279. Setiap ada kenaikan variabel bebas sebesar satu satuan akan meningkatkan variabel terikat yaitu rentabilitas ekonomi sebesar koefisien beta variabel bebas dikalikan dengan besarnya kenaikan yang terjadi.

\section{PEMBAHASAN}

Hasil analisis data dalam penelitian ini menunjukkan bahwa profit margin berpengaruh signifikan terhadap rentabilitas ekonomi pada LPD di Kecamatan Susut tahun 2014-2015. Hal ini dibuktikan dengan hasil analisis data yang menunjukan nilai t-hitung $=5.670>\mathrm{t}$ tabel $=1,66571$ atau $p$-value $=0,00<a=$ 0,05 dengan nilai koefisien beta yaitu $+0,110$. Temuan ini sejalan dengan penelitian yang dilakukan oleh Suharso (2012), yang menyatakan bahwa profit margin berpengaruh terhadap rentabilitas ekonomi, serta sejalan dengan pendapat Riyanto (2001) yang menyatakan bahwa variabel profit margin merupakan faktor yang mempengaruhi rentabilitas ekonomi. Adapun variabel turnover of operating assets tidak berpengaruh terhadap rentabilitas ekonomi pada LPD di Kecamatan Susut periode 2014-2015, ini bisa dilihat dari nilai t-hitung $=1.901>\mathrm{t}$ tabel $=1,66571$ tetapi nilai $p$-value $=0,061$ $>\mathrm{a}=0,05$ hal ini karena dari analisis data rata-rata turnover of operating assets pada tahun 2014 adalah 0.56 kali perputarannya. Sedangkan pada tahun
2015 rata-rata perputaran turnover of operating assetsnya adalah 0,59 kali, hal ini menunjukan bahwa secara rata-rata modal tidak banyak berputar dalam menghasilkan penjualan. Temuan ini tidak sejalan dengan penelitian yang dilakukan oleh Sularso (2012), yang menyatakan bahwa turnover of operating assets berpengaruh terhadap rentabilitas ekonomi

Lebih lanjut dari hasil analisis data dalam penelitian ini menunjukkan bahwa profit margin dan turnover of operating assets secara simultan memiliki pengaruh yang signifikan terhadap rentabilitas ekonomi pada LPD di Kecamatan Susut tahun 2014-2015. Temuan ini sejalan dengan penelitian sebelumnya dari Sularso (2012) yang menyatakan bahwa profit margin dan operating asset turnover berpengaruh terhadap rentabilitas ekonomi, serta hal ini sesuai dengan pendapat Riyanto (2001) yang menyatakan bahwa profit margin dan turnover of operating assets merupakan variabel yang mempengaruhi rentabilitas ekonomi.

Berdasarkan temuan di lapangan bahwa profit margin dan turnover of operating assets secara simultan berpengaruh signifikan terhadap rentabilitas ekonomi pada LPD di Kecamatan Susut tahun 2014-2015, dapat dijelaskan bahwa profit margin yang dimaksudkan untuk mengetahui efisiensi perusahaan dengan melihat kepada besar kecilnya laba usaha dalam hubungannya dengan sales dapat meningkatkan rentabilitas ekonomi. Turnover of operating assets yang merupakan rasio perputaran aktiva perusahaan yang dimaksudkan untuk mengetahui efisiensi perusahaan dengan melihat kepada kecepatan perputaran operating assets dalam suatu periode tertentu mampu meningkatkan rentabilitas ekonomi lewat konsistensi maupun peningkatan dalam kecepatan perputaran operating assets.

Persamaan regresi untuk menggambarkan pengaruh profit margin dan turnover of operating assets terhadap rentabilitas ekonomi adalah $\hat{Y}=0.279$ $+0.110 \mathrm{X} 1+1.664 \mathrm{X} 2+\mu$. Konstanta sebesar 0.279 menyatakan bahwa jika variabel 
bebas dianggap konstan, maka rentabilitas ekonomi adalah sebesar 0.279 . Setiap ada kenaikan variabel bebas sebesar satu satuan akan meningkatkan variabel terikat yaitu rentabilitas ekonomi sebesar koefisien beta variabel bebas dikalikan dengan besarnya kenaikan yang terjadi.

Besarnya koefisien determinasi
(Adjusted R Square) menunjukan
besarnya pengaruh profit margin (X1),
turnover of operating assets (X2),
berpengaruh terhadap Rentabilitas
ekonomi sebesar 0,324 artinya sebesar
$32.4 \%$ Sehingga dapat disimpulkan
bahwa profit margin dan turnover of
operating assets secara simultan
berpengaruh terhadap rentabilitas
ekonomi.

\section{SIMPULAN DAN SARAN SIMPULAN}

Berdasarkan hasil penelitian dan pembahasan dapat disimpulkan hal-hal sebagai berikut. Profit margin berpengaruh terhadap rentabilitas ekonomi pada LPD di Kecamatan Susut periode tahun 20142015. Hal ini ditunjukan dengan nilai thitung $=5.670>$ t-tabel $=1,66571$ atau $p$ value $=0,00<a=0,05$. Turnover of operating assets tidak berpengaruh terhadap rentabilitas ekonomi pada LPD di Kecamatan Susut periode tahun 20142015. Hal ini ditunjukan dengan nilai thitung $=1.901>\mathrm{t}$-tabel $=1,66571$ namun $\mathrm{p}$-value $=0,061>\mathrm{a}=0,05$. Profit margin dan turnover of operating assets berpengaruh secara simultan terhadap rentabilitas ekonomi pada pada LPD di Kecamatan Susut periode tahun 20142015. Hal ini ditunjukan dengan nilai Fhitung $=18,987>$ F-tabel $=3,12$ atau $p$ value $=0,00<a=0,05$. Besarnya pengaruh profit margin dan turnover of operating assets terhadap rentabilitas ekonomi adalah sebesar 0,324 artinya sebesar $32,4 \%$, sehingga variabel profit margin dan turnover of operating assets secara simultan berpengaruh terhadap rentabilitas ekonomi.

\section{SARAN}

Berdasarkan simpulan di atas, maka dapat diberikan beberapa saran sebagai berikut. Pertama bagi Lembaga Pekreditan Desa berdasarkan hasil penelitian yang menyatakan bahwa profit margin berpengaruh signifikan terhadap rentabilitas ekonomi, maka dalam hal ini untuk terus dapat meningkatkan rentabilitas ekonomi laba usaha perlu terus ditingkatkan dengan cara mengurangi atau memperkecil biayabiaya. Turnover of operating assets tidak berpengaruh terhadap rentabilitas ekonomi hal ini disebabkan oleh data riil di lapangan. rata-rata nilai perputaran modal usaha untuk memperoleh pendapatkan operasional dalam kurun waktu dua tahun tersebut sangat kecil yaitu 0,57 kali. Pada akhirnya hasil penelitian ini bisa dijadikan bahan evaluasi dalam menjalankan operasional LPD kedepannya. Kedua bagi peneliti selanjutnya penelitian ini dapat dijadikan salah satu refrensi dan sebagai bahan untuk mendalami objek sejenis.

\section{DAFTAR PUSTAKA}

Elvandari, Dwi Novita. 2010. "Analisis Faktor-Faktor Yang Mempengaruhi Rentabilitas Ekonomi Pada KPRI Di Kabupaten Demak Tahun 20082009". Tersedia Pada http://lib.unes.ac.id/2978/1/6342.pdf (diakses tanggal 21 agustus 2017)

Hanafi, M. Mamduh \& Abdul Halim. 2007. Analisis Laporan Keuangan. Yogyakarta : UPP AMP YKPN

Hariadi. B. 2002. Akuntansi Manajemen. Yogyakarta : BPFE

Husnan, S. \& Enny Pudjiastuti. 2012. Dasar-Dasar Manajemen Keuangan. Edisi keenam cetakan pertama. Yogyakarta. UPP STIM YKPN

Jumingan. 2008. Analisis Laporan Keuangan. Jakarta: PT Bumi Aksara

Kasmir. 2010. Pengantar Manajemen Keuangan. Edisi Pertama. Jakarta: Kencana

------. 2004. Pemasaran Bank. Edisi Pertama. Jakarta:Kencana

------. 2013. Bank dan Lembaga Keuangan Lainnya. Edisi Revisi. Jakarta. Rajawali Pers 
Nurmalasari, Indah. 2009. "Analisis Pengaruh Rasio Profitabilitas Terhadap Harga Saham Emiten LQ45 Yang Terdaftar Di Bursa Efek Indonesia Tahun 2005-2008" Tersedia pada http://www.gunadarma.ac.id/librar y/articles/graduate/economy/2009 IArtikel 20205630.pdf (diakses tanggal 2 Desember 2017)

Peraturan Daerah Provinsi Bali Nomor 4 Tahun 2012

Riyanto, Bambang. 2001. Dasar-Dasar Pembelanjaan Perusahaan. Edisi Keempat Yogyakarta : BPFE

Sularso, Ely. 2012. Pengaruh Profit Margin dan Operating Asset Turnover Terhadap Rentabilitas Ekonomi. Tersedia Pada https://jurnalefektif.janabadra.ac.id

Sartono, Agus. 2010. Manajemen Keuangan Teori Dan Aplikasi. Cetakan Keempat. Yogyakarta: BPFE

Suyadi. 2003. Analisis Rentabilitas Ekonomis Sebagai Alat Ukur Efisiensi Penggunaan Dana Pada Koperasi Sejahtera Perum Pegadaian Surakarta Di Surakarta. Tersedia pada https://www.google.co.id/url?sa=t\&rct $=\mathrm{j} \& \mathrm{q}=\&$ \&esrc $=\mathrm{s} \&$ source $=$ web $\& \mathrm{~cd}=1 \& \mathrm{c}$ $\mathrm{ad}=\mathrm{rja} \&$ uact $=8 \& \mathrm{ved}=0$ ahUKEwjUleq $\mathrm{mn}-$

vXahVKKo8KHQ8jCE4QFggoMAA\& url=https $\% 3 \mathrm{~A} \% 2 \mathrm{~F} \% 2 \mathrm{Fdigilib} . u n s . a c . i$ d\%2Fdokumen\%2Fdownload\%2F58
29\%2FMTY1MDE\%3D\%2FAnalisisrentabilitas-ekonomis-sebagai-alatukur-efisiensi-penggunaan-danapada-koprasi-Sejahtera-PerumPegadaian-Surakarta-di-Surakartaabstrak.pdf\&usg=AOvVaw0Vq3E7Se WOWHyLb8BUhBF7 (diakses pada 20 November 2017)

Sugiyono. 2010. Metode Penelitian Bisnis. Cetakan Kelimabelas. Bandung: ALFABETA 